\title{
APRICA REVIEW
}

AFRICA FOCUS, Vol.4, Nr.3-4, pp. 173-186.

AN UP-TO-DATE GEOGRAPHICAL, HISTORICAL, POLITICAL AND ECONOMIC SUMMARY OF THE AFRICAN COUNTRIES*

Prepared by : F. Pauwels, P. Van Damme, D. Theeten, D. Beke, S. Hoste.

\section{ANGOLA}

1. Official name: People's Republic of Angola

Republica Popular de Angola

2. Geography:

2.1. Situation: Angola lies in the west-central part of southern Africa, between $6^{\circ} \mathrm{S}$ and $18^{\circ} \mathrm{S}$, and $11^{\circ} 45^{\prime} \mathrm{E}$ and $24^{\circ} \mathrm{E}$. The district of Cabinda, north of the Zaïre river, is part of Angola.

2.2. Total area: $1246700 \mathrm{~km}^{2}$ (incl. Cabinda: $7270 \mathrm{~km}^{2}$ ).

2.3. Natural regions: a $70-80 \mathrm{~km}$ large coastal zone separates the central highlands, ranging from 1000 to $2000 \mathrm{~m}$ altitude, from the Atlantic Ocean. These plateaux are bordered by the Cristal Mountains in the north and the Chela Mountains in the south. Major river systems are the Kasai and the Zambezi-Okavango system, where altitudes well over $1000 \mathrm{~m}$ are found. Only the southern coastal zone is suited for cultivation.

2.4. Climate: tropical, with temperatures modified by the altitude and with a marked dry winter season throughout the country. The intertropical convergence zone brings

* Every issue of AFRIKA FOCUS will provide a survey of two or three African countries. The choice will be related, if possible, to articles in the issue. 
rainfall, decreasing from the north to the south. The coastal zone has a lower rainfall, caused by the cooling effects of the Benguela current, restricting both convection and land temperatures, and thus lowering precipitation.

\section{Population:}

3.1. Total population: $8.9 \mathrm{mln}(1986)$, urban population: $25 \%$.

3.2. Population density: 7.2 per $\mathrm{km}^{2}$ (1986).

3.3. Population growth rate: $2.5 \%(1980-1985)$.

3.4. Capital: LUANDA, with $1.2 \mathrm{mln}$ inh. (1981).

3.5. Principal languages: Chokwe, Kikongo, Kimbundu, Kwanyama, Lingala, Luvale, Songu, Umbundu, Portuguese (official and commercial language) and French.

3.6. Religion: 40\% Roman Catholic, 10\% Protestant, traditional religions.

4. History:

Like most African countries, Angola was discovered by the Portuguese sailors, followed by trade settlements. The conference of Berlin (1885) confirmed the Portuguese domination. After a long liberation war, Angola acquired independence in November 1975. As a result of the liberation movement, the power was seized by the MPLA. FNLA and UNITA conducted military campaigns against the MPLA-regime. Until 1984, UNITA was openly supported by South Africa and US-aid was received in 1986. FNLA is inactive since 1984. UNITA operates mainly in the central and southern part of the country.

5. Nature of political system:

The leadership of the country is centred on the MPLA-PT (Movimento Popular de Libertacao de Angola - Partido de Trabalho). The Congress convenes once every four years to 
elect the President and the 90 members of the Central Committee. This Committee elects a 13 member Political Bureau. The Political Bureau, headed by the party (and state) President, José Edwardo Dos Santos, is the policymaking body. A national People's Assembly is established in November 1980. Of the 223 members, 20 are nominated by the Central Committee and 203 are elected, for a 3 year term, by electoral colleges composed of representatives chosen by all "loyal" citizens over 18 in their work or living places.

6. Economy:

GDP: agriculture 48\%, industry 23\% (1979).

Employment: agriculture 57\% (1981).

6.1. Mining:

Angola has important mineral deposits. Iron ore and diamonds are major products besides manganese. The exploitation of copper deposits has not yet started. Petroleum production is most important by far, but due to the civil war, the Benguela railway is closed, resulting in a major drag to further development.

6.2. Agriculture:

$2.8 \%$ of the total area is arable land or cultivated with permanent crops (1984). Subsistence agriculture, along with some stock raising or extensive pastoralism is practised by the greater part of Angola's population. Cassava is the major food crop, coffee the major cash crop. Sugar-cane, sisal, oilpalm, cotton and bananas are also important, mostly for domestic use.

6.3. Livestock:

$23 \%$ of the total area is permanent pasture (1984). The NW and the NE are infected by the tsétse-fly which inhibites livestock raising. Livestock industry suffers from the general poor grassland quality: heads of cattle (3.2 $\mathrm{mln})$, sheep (225 000), goats $(935000)$, pigs $(400000)$ and poultry $(5.4 \mathrm{mln})$. Total meat production of $80000 \mathrm{t}$ 
(1981).

6.4. Forestry and woodland:

Woodlands and forests are important elements of the ecology and they cover $43 \%$ of the total area (1984). The richest timber forests are in the $\mathrm{NW}$ tropical forest areas. Among the tall trees of commercial value are Terminalia superba (Limba), Entandrophragma utile (Sapele), Khaya spp. (Acajou), Chlorophora excelsa (Iroko), Oxystigma oxyphyllum in the northern regions and in Cabinda. Between Zaïre and Cuanza Norte, commercial species also include Pteleopsis diptera, Pterocarpus tinctorius, Albizzia spp. and Diospyrus mespiliformis. Timber exploitation is chiefly for local needs. Reforestation has been undertaken on woodlands on the central plateaux, comprising mainly Rucalyptus camaldulensis, Eucalyptus saligna, Cupressus lusitanica, Pinus patula and Casuarina equisetifolia.

6.5. Fishery:

Important catches on the central and southern coast. Most of the fishing is done with small boats. Annual catches fluctuate between $75000 \mathrm{t}(1976)$ and $470000 \mathrm{t}$ (1973). Fresh and dried fish as well as fish products, fish oil and fish meal are exported.

6.6. Industry:

Relatively diversified: major industries are food processing, textile, cement factories and petroleum refineries.

6.7. Weights, measures and currency:

$\mathrm{kg}$, meter

1 Kwanza (K) $=100$ Lwei

1 US $\$=70 \mathrm{~K}$ (June 1989)

7. Trade:

Total exports amount to $2029 \mathrm{mln}$ US \$, total imports amount to $1003 \mathrm{mln}$ US \$ (1984).

Major export products are petroleum (30\%), coffee (25\%), diamonds $(10 \%)$, fish products, sisal and timber. 
No recent statistical data are available, due to the recent change in orientation of the Angolese regime.

8. Miscellaneous:

Literacy: 20\% (1980), but an intensive campaign was launched in 1976 aimed at eliminating illiteracy by 1985 . Membership of international organisations:

COMECON (observer status), GATT (provisional), ILO, OAU, SADCC, UN, WHO, African Development Bank, Arab Bank for Economic Development in Africa (recipient), Economic Commission for Africa.

Angolan Embassy in Belgium: Franz Merjaystraat 182

1180 Brussel

Tel. 02/347.24.92

Belgian Embassy in Angola: Avenida Paulo Dias de Novais 93, 3d floor

C.P. 1203.

Luanda, Angola 


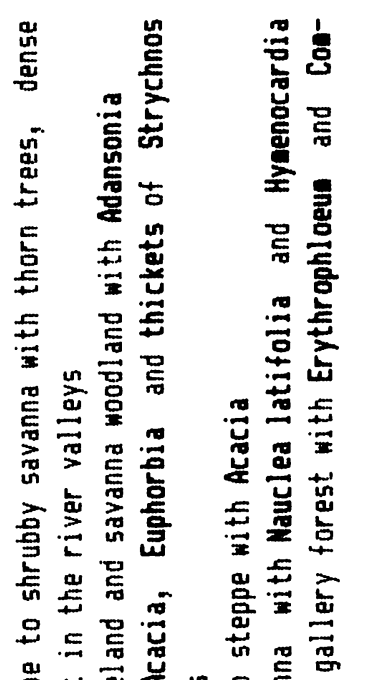

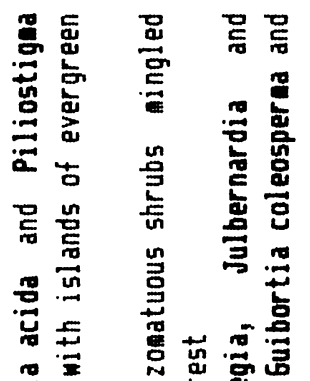

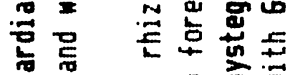

듷

䒚告至

总

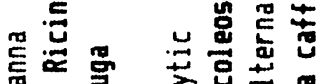

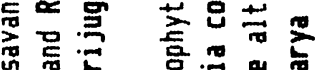

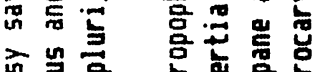

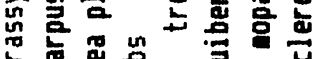

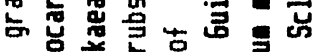

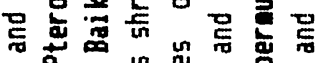

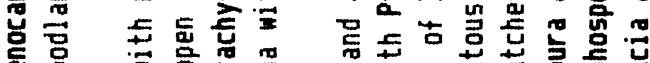

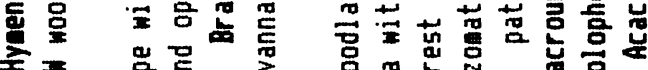
全 总总视

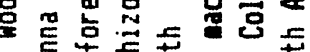

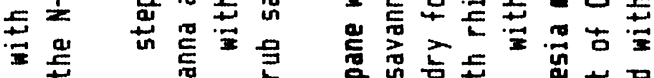

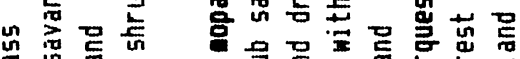

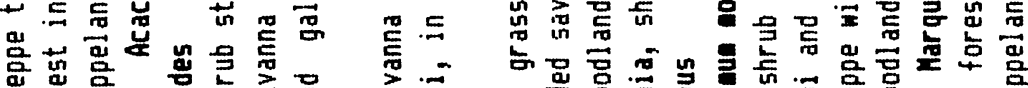

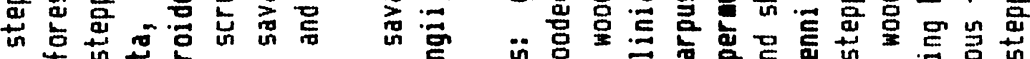

4
-
0
0
2
4

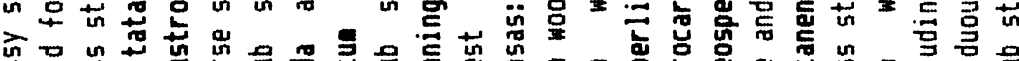

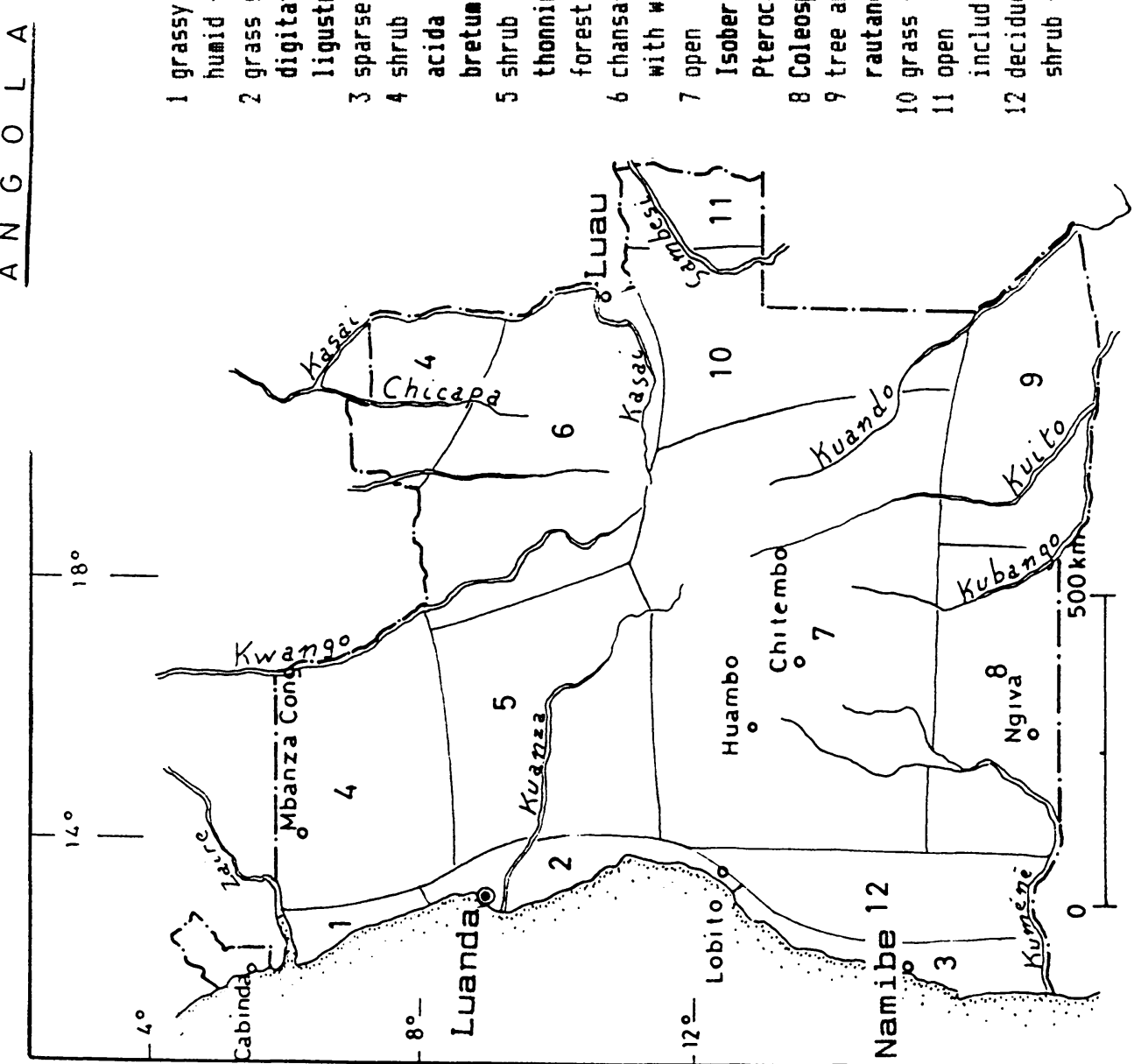




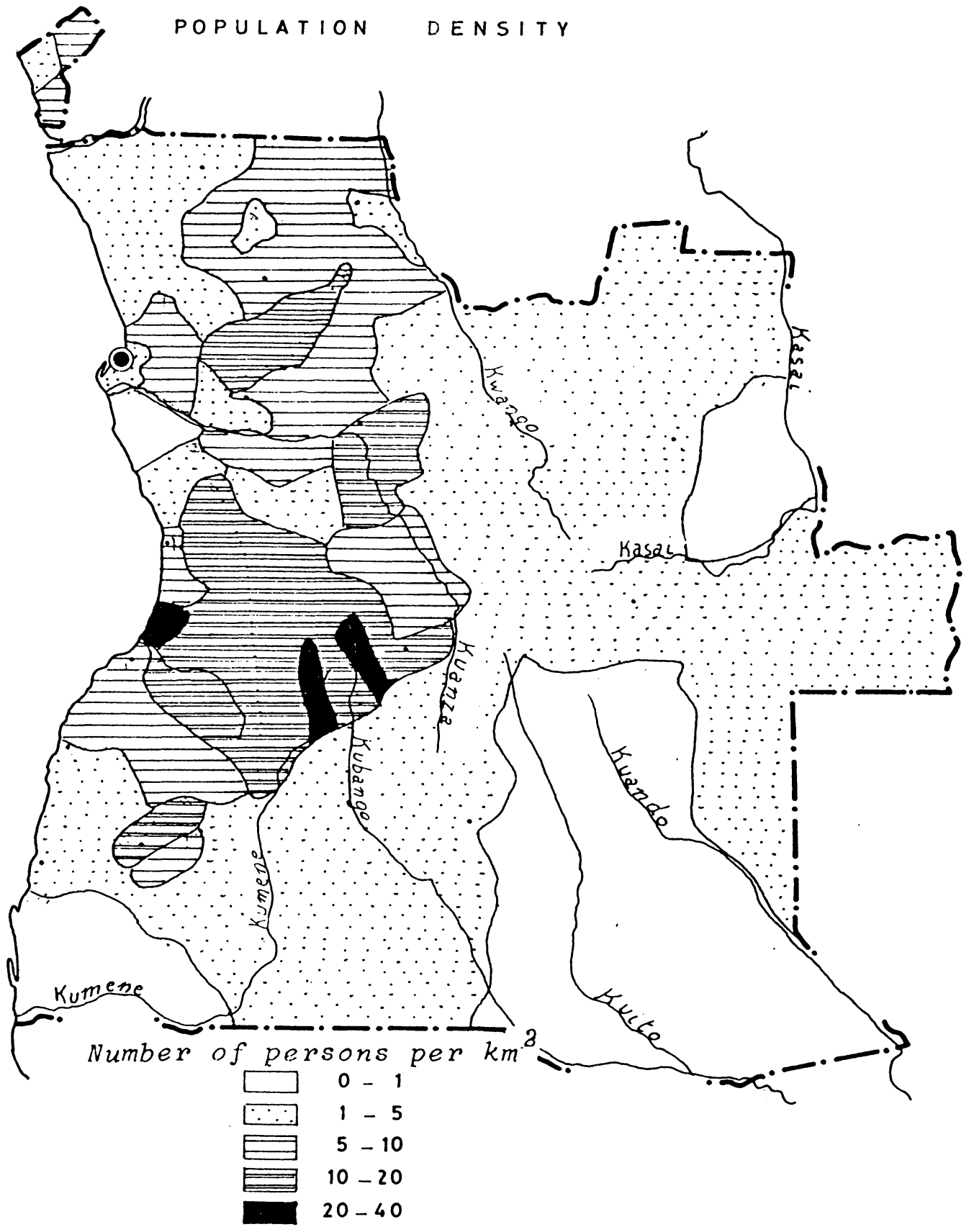



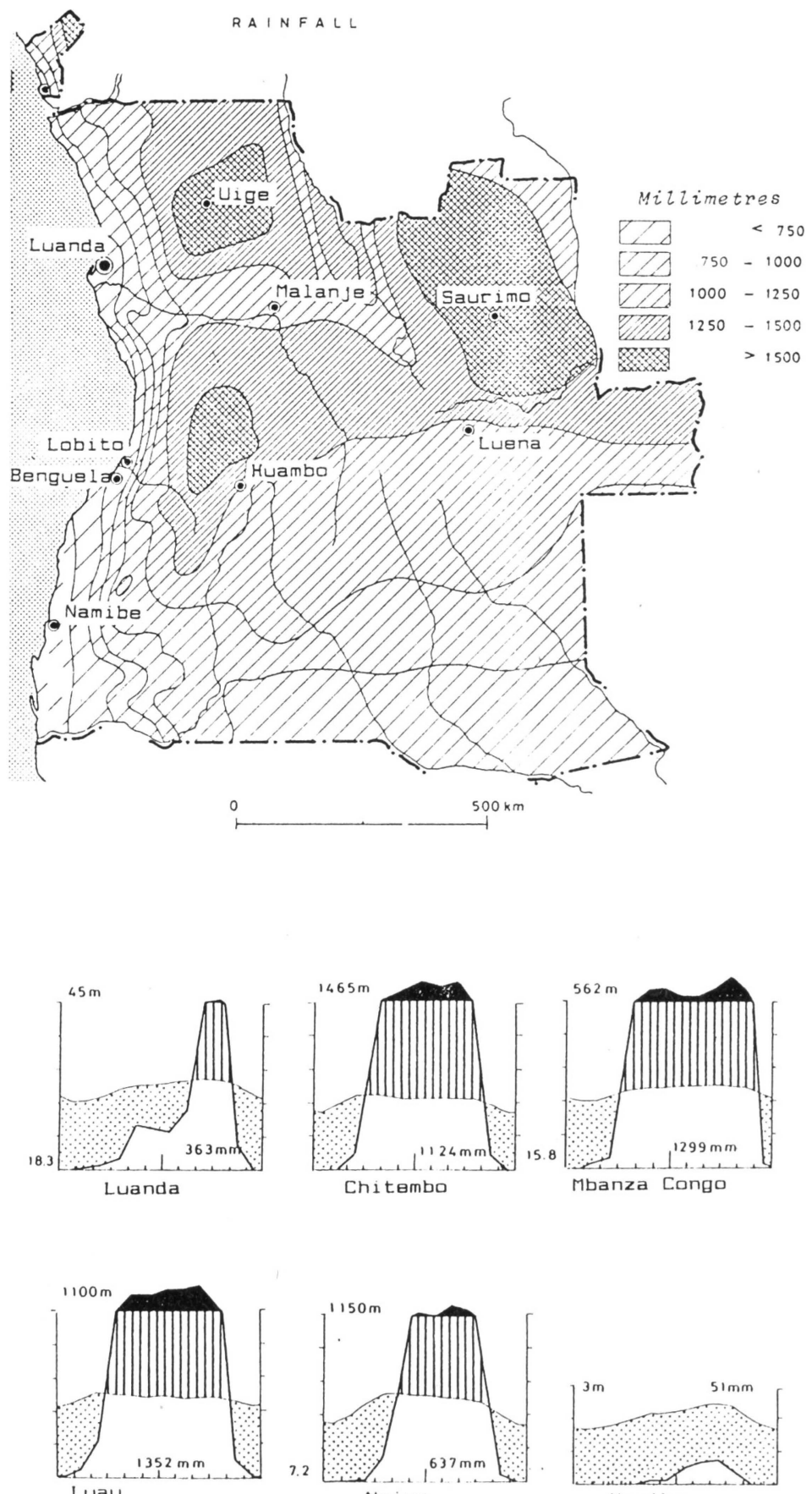

Ngiva

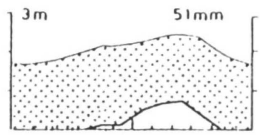

Namibe 


\section{LIBYA}

1. Official name: The Great Socialist People's Libyan Arab Jamahiriya (G.S.P.L.A.T.)

Al-Jamahiriya al-Arabiyah al-Libiya ashShaabiyah al-Ishtirakiyah

2. Geography:

2.1. Situation: Libya is situated on the central north coast of Africa between $9^{\circ} \mathrm{E}$ and $25^{\circ} \mathrm{E}, 19^{\circ} \mathrm{N}$ and $33^{\circ} \mathrm{N}$.

2.2. Total area: $1759540 \mathrm{~km}^{2}$.

2.3. Natural regions: a small triangular coastal zone in West Libya is followed by the Jebel Tripolitania which consists of two series of ridges. To the south the Jebel grades gently down to the stony plateau of the el Hombra dessert. The Jebel el Akhdar in East Libya is similar but a little higher in average $(1000 \mathrm{~m})$. Southwards it slopes gently down to the rocky desert. Northwards it grades towards the sea in broad limestone terraces with a coastal zone in the east. The rest of the country consists of desertic plain.

2.4. Climate: is desertic throughout the country, except in the Tripoli region and Cyrenaica which have a mediterranean climate. The Ghibli, a hot dry dust-loaden desert wind, blows in spring and autumn and lowers humidity in the coastal zone which is normally rather high.

3. Population:

3.1. Total population: 3.8 (1985), urban population: $60 \%$.

3.2. Population density: 2.0 per $\mathrm{km}^{2}$.

3.3. Population growth rate: $3.9 \%(1980-1985)$.

3.4. Capital: TRIPOLI, 990000 inh. (1984); in January 1987 Colonel Qadhafi designed HUN, a town $650 \mathrm{~km}$ to the southeast of Tripoli, as the administrative capital of the country. 


\section{I B Y A}

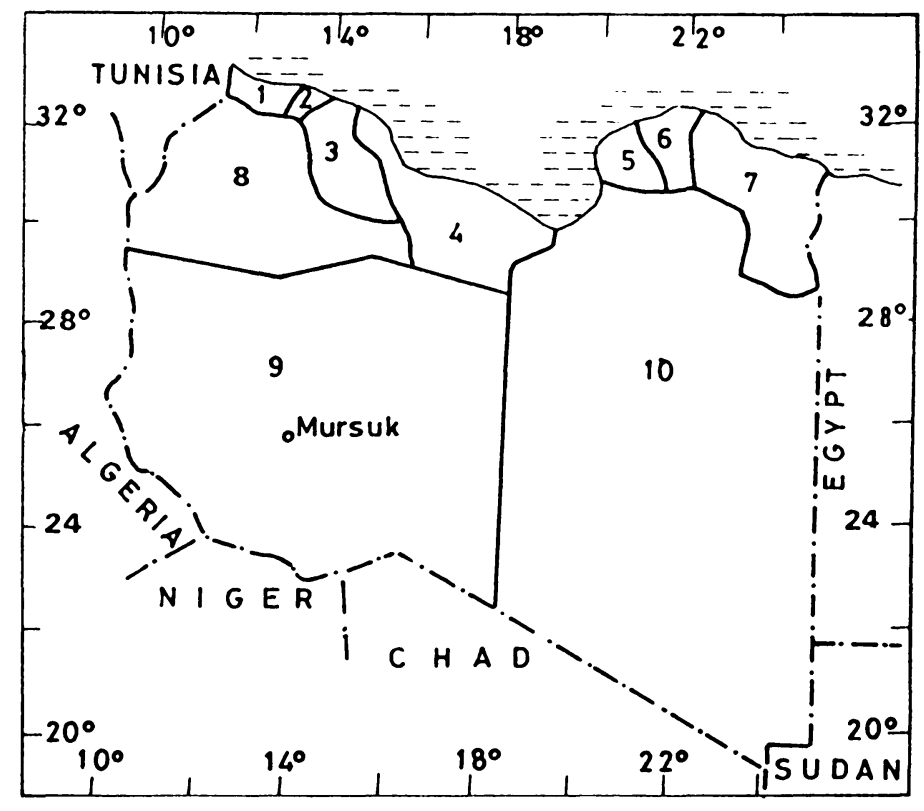

1 Sauija

2 Tripoli

3 Chums

4 Misrata

5 Bengasi

6 Dschabal al Achdar

7 Darna

8 Dschabal al Gharb

9 Fessan

10 Al Kalig 
3.5. Languages: Arab (also official language), Berber.

3.6. Religion:Islam, small Christian communities.

\section{History:}

Libya has always been dominated by the ruling powers of the Mediterranean Sea. Inland conflicts for ruling oases, pastureland and caravan roads and an alternating balance of power among sedentary farmers and nomads hampered political unification. The colonization of Libya by the Italians (1911-1943) was a period of armed conflicts, harsh repression and development of the coastal zone. December 1951 Libya acquired independence by agreement in the General Assembly of the UN.

5. Nature of political system:

Executive power is formally held by the General People's Committee which is appointed by the General People's Congress which is made up of representatives from local committees. Colonel Qadhafi resigned formal office but remains as head of the Revolutionary Committees and the central figure in the political process.

Voting qualifications: universal adult suffrage.

6. Economy:

GDP:agriculture: $4 \%$, industry: $57 \%$, services: $39 \%$ (1985). Employment: agriculture: 18\%, industry: $30 \%$, services: $53 \%$ (1980).

6.1. Mining:

The oil industry is by far the major mining activity. 1983 production was estimated at 600-650 $000 \mathrm{~b} / \mathrm{d}$. Seçond in line is natural gas. Other minerals exploited/under study: gypsum, iron ore and phosphates. 


\subsection{Agriculture:}

$1.2 \%$ of the total area is arable land or cultivated with permanent crops (1984). Most of this area lies in Tripolitania, and part of it is irrigated. Main food crops are wheat, barley, vegetables and citrusfruit. Almonds, ricinus and groundnuts are also cultivated. The olive production, which is partly exported, is important.

6.3. Livestock:

$7.5 \%$ of the total area is permanent pasture (1984). The nomadic shepherd population covers approximately $40 \%$ of the total area with its extensive grazing system, mostly concentrated in the vicinity of wells and oases.

6.4. Forestry and woodland:

In eastern Libya $60 \quad 000$ ha of eucalyptus and cupressus were planted to prevent soil erosion. Most of the existing woodland is macquis which is used for firewood.

6.5. Fishery:

Is poorly developed. A annual catch of $6000 \mathrm{t}$ is locally consumed to enrich the normal food with its usual low in protein content.

6.6. Industry:

Is based on petrochemical plants and transformation of agricultural products. The housebuilding industries and cement plants have been strongly developed in recent years.

6.7. Weights, measures and currency:

$\mathrm{kg}$, meter

1 Libyan Dinar (LD) $=1000$ dirhams

1 US $\$=0.30$ LD (Nov. 1984)

7. Trade:

Total exports amount to $10841 \mathrm{mln}$ US \$ (1985) of which oil represents $99 \%$. Main clients are the EEC, the USA, Turkey, Brasil, Argentina and Japan.

Total imports amount to $6186 \mathrm{mln}$ US \$ (1985). Main suppliers are the EEC, the USA, Romania and Argentina. 

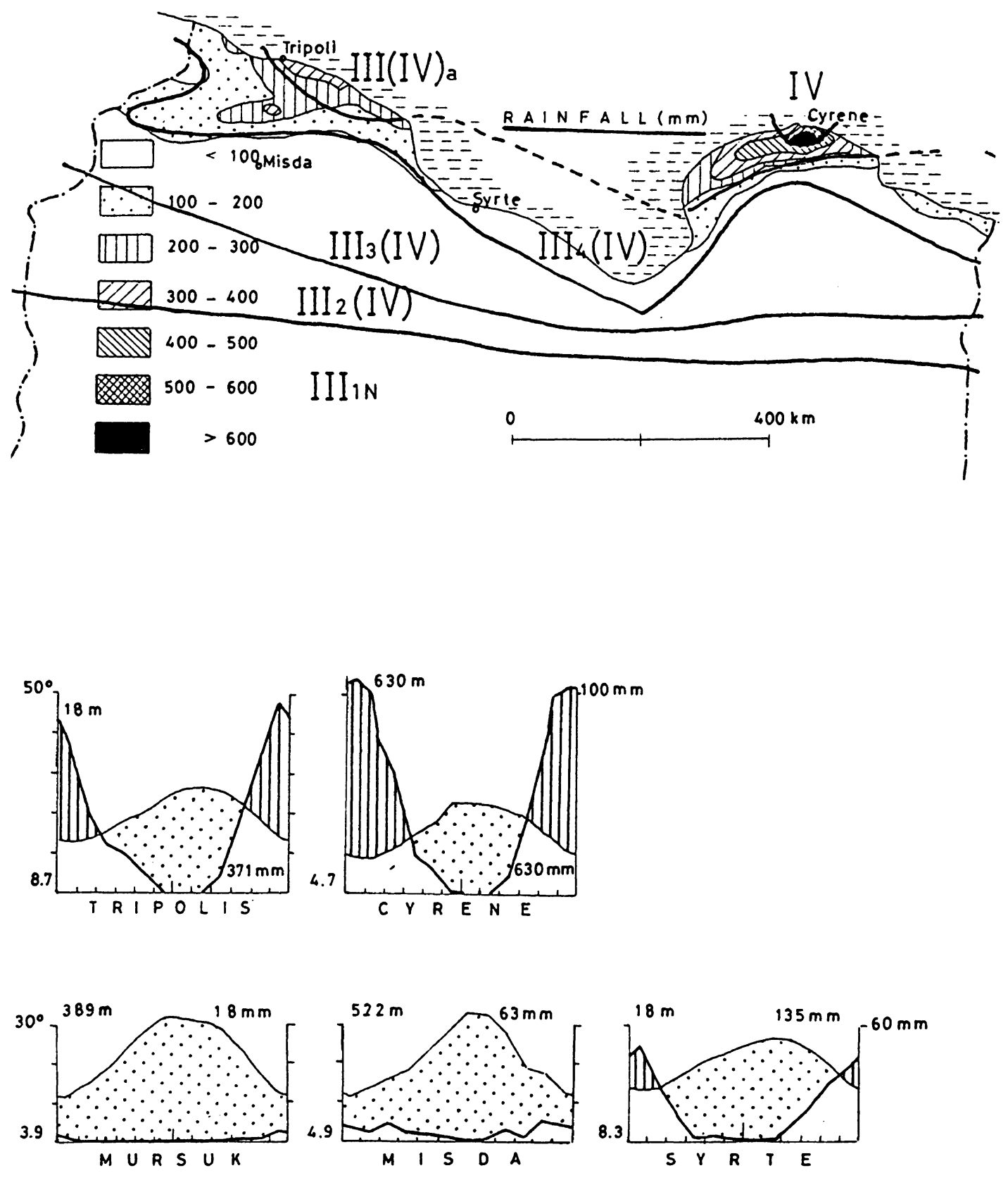
8. Miscellaneous:

Literacy: estimates vary considerably (40-60\%). World Bank classification: Libya belongs to the high-income oil exporting countries. The GDP per capita reached 8520 US $\$(1984)$.

Membership of international organisations:

ILO, IMF, OAPEC, OAU, OPEC, UN, WHO, African Development Bank, Arab Common Market, Arab Fund for Economic \& Social Development, Arab League, Islamic Conference, Islamic Development Bank, World Bank.

People's Bureau of the G.S.P.L.A.J. in Belgium:

Victorialaan 28

1050 Brusse 1

te1 $02 / 649.16 .56$

Belgian Embassy in Libya: Sharia Abu Ubaida Ibn Jaraj

No. 1

POB 663

Tripoli, Libya 